\title{
Pinus mugo shrubs on peat bogs in the Tatra National Park
}

\author{
Anna Maria Ociepa1* ${ }^{1 *}$ Antoni Zięba² \& Tomasz Zwijacz-Kozica²
}

\section{Article info}

Received: 16 May 2021

Revision received: 28 Oct. 2021

Accepted: 2 Nov. 2021

Published: 31 Dec. 2021

\section{Associate Editor}

Elżbieta Cieślak

\begin{abstract}
Pinus mugo shrubs on peat bogs in the Tatra National Park (TNP) were for the first time described as a separated plant association by Obidowicz (1975) from only two mires. Since then, there have been no studies on peat bogs in the TNP and they have not been mentioned in the list of vegetation types of the Park. The research regarding the dwarf pine shrubs on mires in the Tatra Mountains was carried out in 2019. We mapped all patches of such vegetation (total $\sim 2$ ha) on which we made 26 relevés. P. mugo shrubs on peat bogs occur within the complex of mire habitats, such as Norway spruce bog woodlands, raised bogs and poor fens. The shrub layer is dominated by Pinus mugo with admixture of dwarfish Picea abies. Typical plants of the herb layer are Vaccinium myrtillus, V. vitis-idaea, Eriophorum vaginatum and Oxycoccus palustris, whereas the most common mosses are Sphagnum magellanicum, S. capillifolium, S. russowi, Pleurozium schreberi. P. mugo shrubs on peat bogs in the TNP belong to the association Sphagno magellanici-Pinetum mugo.
\end{abstract}

Key words: krummholz, mires, mountain wetlands, Sphagno magellanici-Pinetum mugo, Tatra Mountains

\section{Introduction}

Pinus mugo shrublands occur in Central Europe in two major types: (1) subalpine, such as Seslerio albicantisPinetum mugo (Šoltésová 1974) Šibík in Jarolímek et Šibík 2008, Adenostylo alliariae-Pinetum mugo (Sillinger 1933) Šoltésová 1974, Dryopterido dilatatae-Pinetum mugo Unar et al. 1985, Cetrario islandicae-Pinetum mugo Hada 1956, and (2) azonal peat bog communities (Šibík et al. 2010). Dwarf pine (Pinus mugo) shrubs on peat bogs occur in the Carpathians, Sudetes, Alps, Dinarids, Rila and Pirin Mountains (Šibík et al. 2010). They grow in the montane and subalpine zones between 700-1800 m a.s.l. (Šibík et al. 2008). In Poland, studies regarding these shrublands were carried out in the Sudetes (Potocka 1997, 2001), whereas in the Tatras they were not sufficiently described. First phytosociological studies in the Tatra Mountains did not include $P$. mugo shrubs on peat bogs as a separate plant association. However, Szafer et al. (1927) in their work regarding the vegetation of Kościeliska Valley mentioned such a plant community as a successional stage on peat bogs at the foothills of Tatras. In the phytosociological table of dwarf pine shrubs, they included 5 relevés with abundant occurrence of Sphagnum capillifolium.

Pawłowski et al. (1928) in their work concerning the plant communities of Rybi Potok Valley (High Tatras) also described vegetation of Rybie Stawki mires. The

\footnotetext{
${ }^{1}$ Filia UP Zakopane, skrytka nr 17, 34-511 Kościelisko, Poland

2 Tatra National Park, Kuźnice 1, 34-500 Zakopane, Poland

*Corresponding author e-mail: amociepa@interia.pl
}

description included P. mugo krummholz. Unfortunately, there is lack of information regarding their characteristics, especially moss layer.

Obidowicz (1975) was the first who described P. mugo shrubs on peat bogs from the Polish Tatras. He described them as Pinus mugo-Vaccinium uliginosum community from two mires, Toporowy Staw Wyżni (variant with Empetrum nigrum) and Pańszczycka Młaka.

Balcerkiewicz (1984), in his work regarding the vegetation of Pięć Stawów Polskich Valley, mentioned the P. mugo krummholz dominated with Sphagnum mosses. There is no information about dwarf pine shrubs on peat bogs in the floristic documentation prepared for the Management Plan of Tatra National Park (Mirek et al. 2013a, b). Therefore, they are also not included as a plant association in the Management Plan of Tatra National Park (Rozporządzenie... 2021). However, the description of the Natura 2000 habitat Bog woodlands in the Tatras shows that this habitat also encompasses such shrublands.

The aim of this work was to characterize P. mugo shrubs on peat bogs in the Tatra National Park based on the relevés collected within the entire range of these shrublands.

\section{Materials and methods}

This study was conducted in the Tatra National Park, encompassing $211.8 \mathrm{~km}^{2}$ and protecting the entire area of the Polish Tatra Mountains, the highest range of the Carpathians (Fig. 1). The areas of the Tatra National Park 


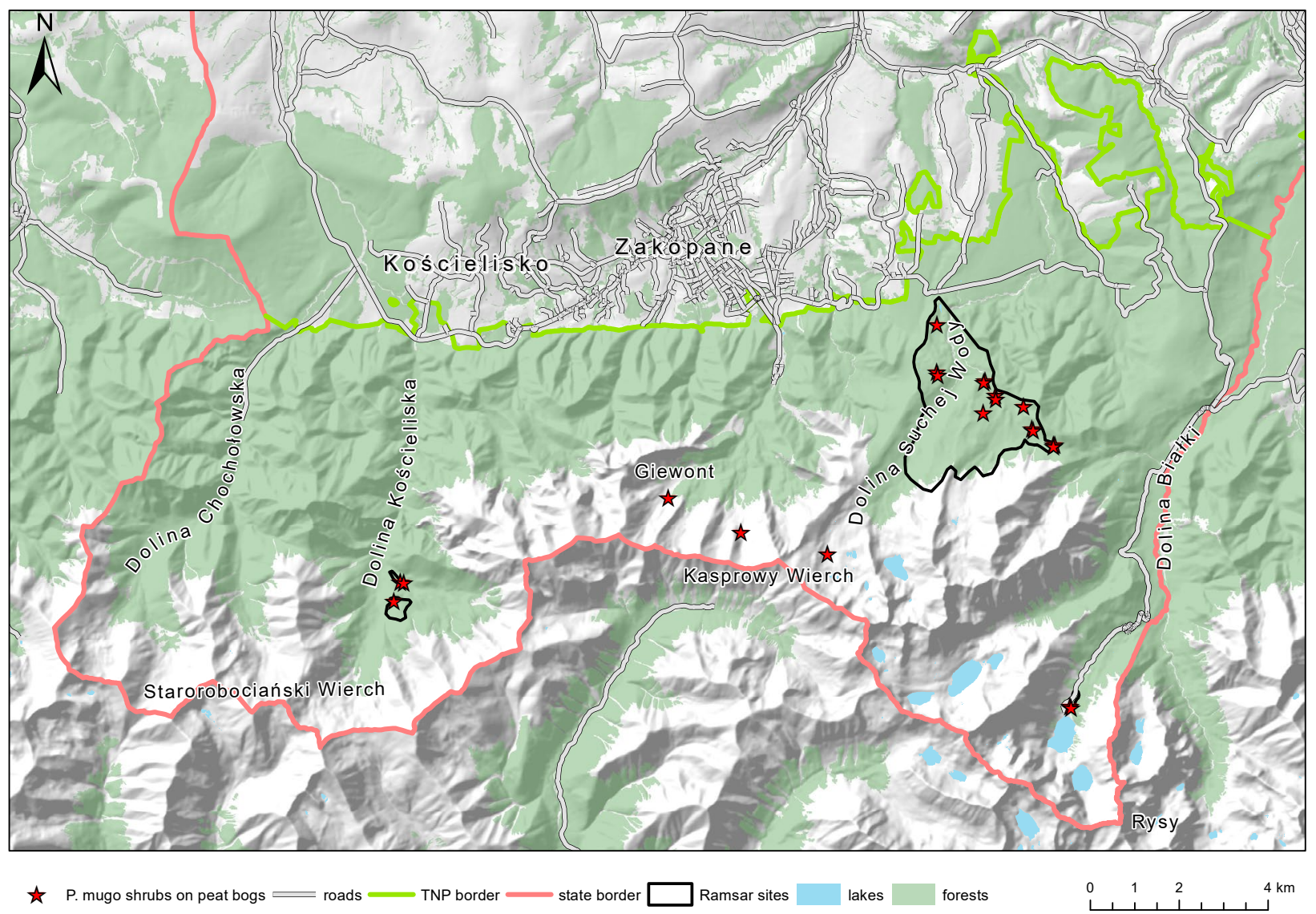

Figure 1. Location of the study sites in the Tatra National Park.

with highest concentration of peat bogs were identified in 2018 in the list of Ramsar Wetland Sites (Ramsar sites information service: https://rsis.ramsar.org/ris/2341; Kauzal \& Zięba 2018).

P. mugo shrubs on peat bogs occur within the complex of mire habitats, such as Norway spruce bog woodlands, raised bogs and poor fens (Figs 2-3). Their patches cover a relatively small area in the Tatra National Park (few hectares - Mirek et al. 2013b, unpubl.). They emerged between the ridges of lateral moraines and slopes of the valleys and between the ridges of recessional moraines. In the second case, they emerged mostly in kettle holes (Derkacz 2006; Łajczak 2014; Zasadni 2015). Both the area and thickness of peat are diversified. Most of the mires are topogenic with only a few of them being typical ombrotrophic bogs. Some wetlands represent both types.

$P$. mugo shrubs on peat bogs were mapped in the vegetation period of 2019, based on the topographic method (Faliński 1990). Field mapping was done using the GPS etrex 30x. Furthermore, we made 26 relevés in these shrublands (Braun-Blanquet 1964, Dzwonko 2007). The area of relevés varied from 50 to $100 \mathrm{~m}^{2}$. In a single case, the area was smaller at $25 \mathrm{~m}^{2}$.

We detected 14 patches of $P$. mugo shrubs on peat bogs in the Tatra National Park. Their total area covers $\sim 2$ ha. They occur on flat terrains between 1177-1640 m a.s.1. Geological substrate consists of peats and peat loams (SMGT 2016) on which peat soils emerged (Skiba et al. 2015).
We mapped all patches of dwarf pine shrubs on peat bogs in the montane zone of Tatra Mountains. P. mugo krummholz on peat bogs in the subalpine zone (above timberline) were not a subject of this research, except two mires located in the Goryczkowa Valley and in the vicinity of Litworowy Staw. There are a few patches of such shrublands in the subalpine zone of Gąsienicowa and Pięć Stawów Polskich Valleys and probably in other parts of the Tatras as suggested by data from relevés made by Szafer et al. (1927). However, it is difficult to find them in the dense subalpine thickets of P. mugo.

The nomenclature of vascular plants and pteridophytes followed Mirek et al. (2002), mosses followed Ochyra et al. (2003), liverworts followed Szweykowski (2006) and lichen nomenclature followed Fałtynowicz \& Kossowska (2016).

Constancy in the phytosociological table (Tab. 1) was calculated using JUICE 7.1 software (Tichý 2002).

\section{Results}

P. mugo is a dominant species in all patches of studied shrublands, accompanied by Picea abies. The most common plants in the herb layer are Vaccinum myrtillus, V. vitis-idaea, Eriophorum vaginatum and Oxycoccus palustris (Fig. 4E-H). The latter two were not found only on Butorów peat and in a single relevé in Tomanowa Valley. These are peat bogs with relatively tall and most dense krummholz of $P$. mugo. The moss layer is dominated by 

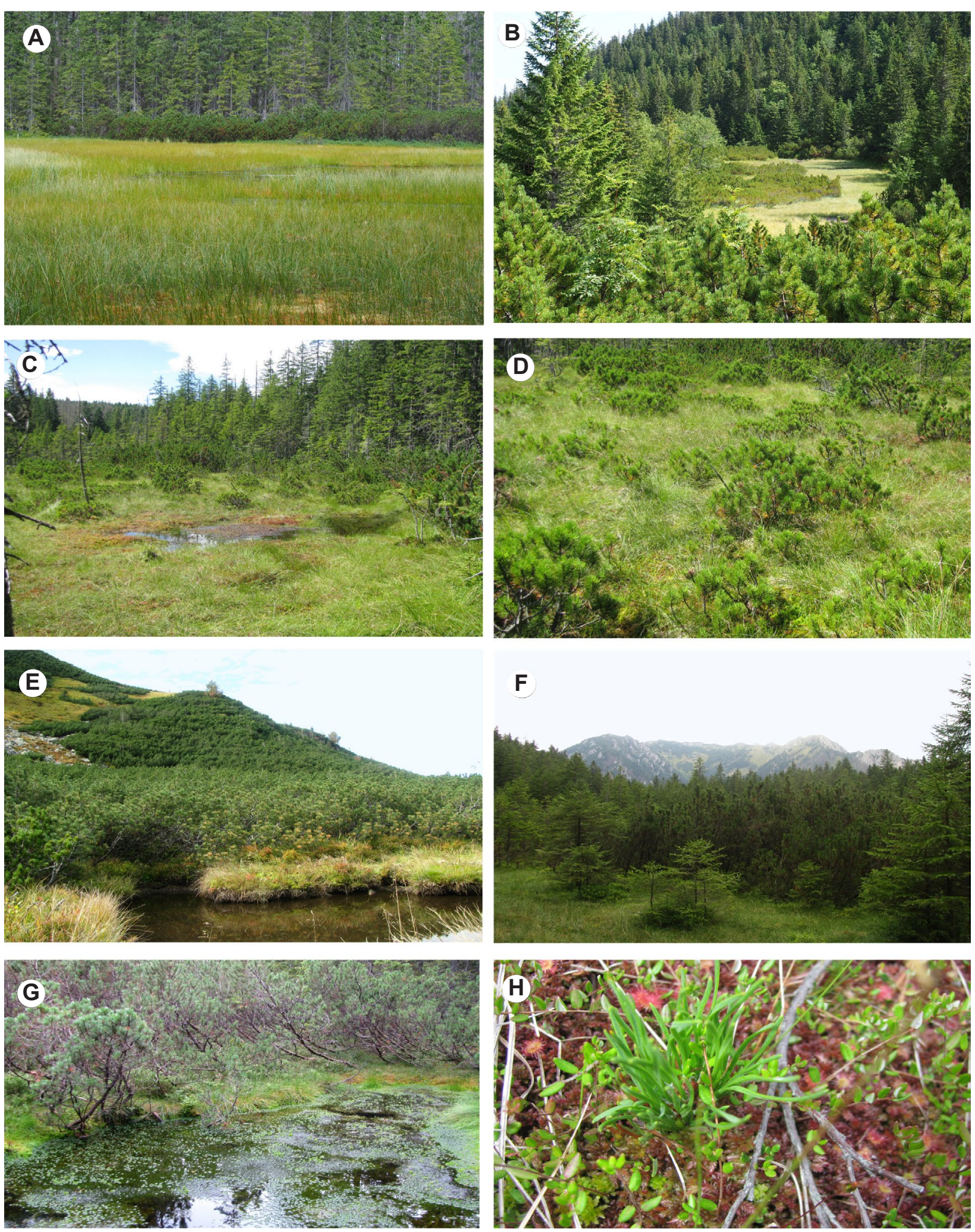

Figure 2. Pinus mugo on peat bogs in the Tatra National Park. A - Toporowy Staw Wyżni: belt of $P$. mugo shrubs and Norway spruce bog woodlands; B - Dolina Kondratowa: P. mugo shrubs surrounded by poor fen and raised bog; C-D - Kotlinowy Wierch; C - scattered P. mugo on peat bogs, dense shrublands and Norway spruce bog woodlands, D - scattered P. mugo on peat bogs; E - Dolina Goryczkowa - P. mugo shrubs on peat bogs and subalpine dwarf pine krummholz; F-G - Dolina Tomanowa: P. mugo shrubs on peat bogs; $\mathrm{H}-$ P. mugo growing among Oxycoccus palustris, Drosera rotundifolia and Sphagnum magellanicum.

Sphagnum magellanicum, S. capillifolium, S. russowi and Pleurozium schreberi (Table 1).

According to Matuszkiewicz (2008), the characteristic species of Pino mugo-Sphagnetum which were found in the analyzed patches are P. mugo and Melampyrum pratense. Furthermore, common species that occur in these shrublands are those representing the alliance of acidophilous Norway spruce forests (Piceion abietis) such as Homogyne alpina, Listera cordata, Picea abies and S. girgensohnii. The characteristic plants for 

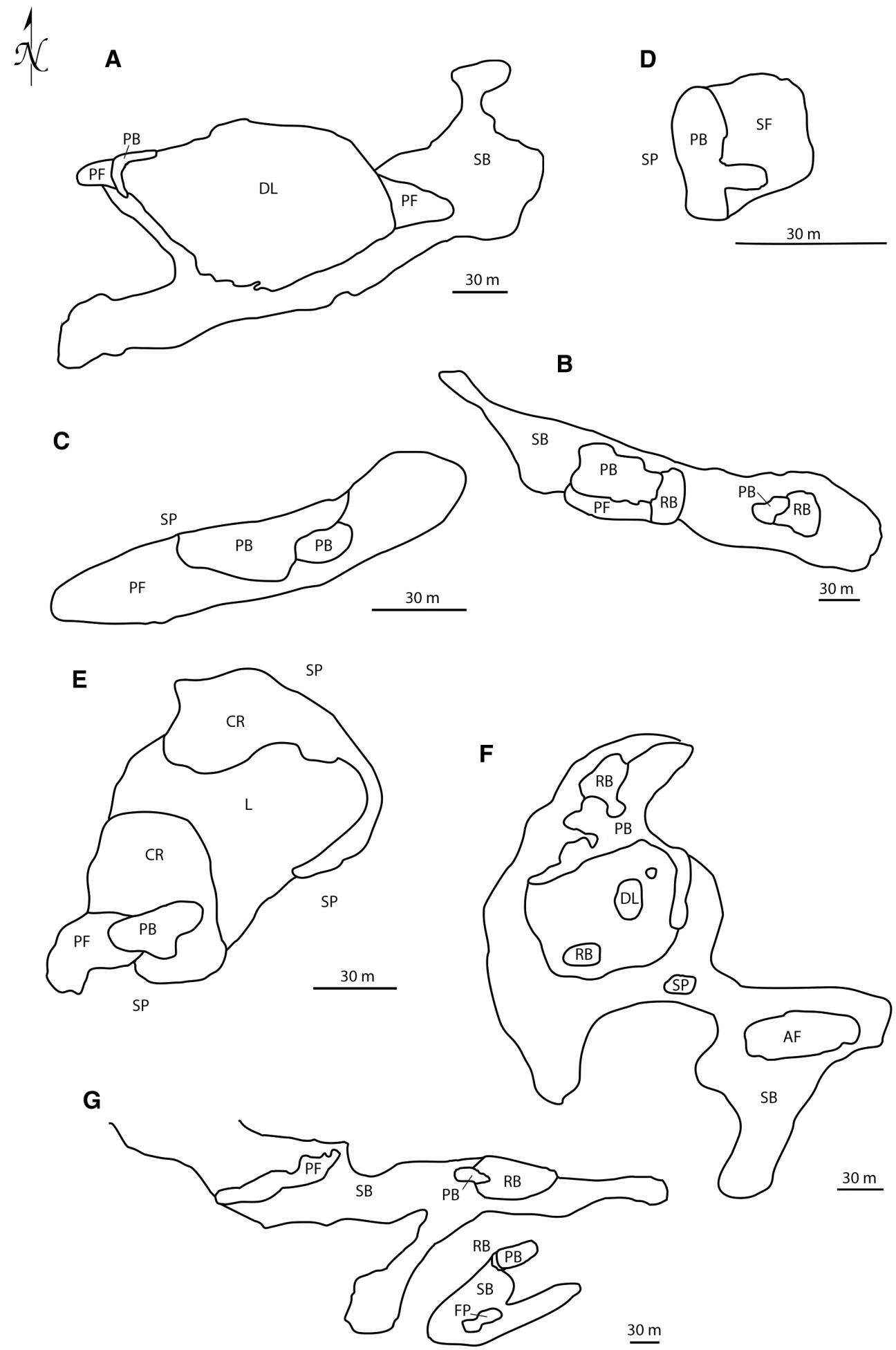

Figure 3. Vegetation types in the study sites. A - Smreczyński Staw; B - Dolina Tomanowa; C - Dolina Kondratowa; D - Dolina Goryczkowa; E - Litworowy Staw; F - Toporowy Staw Wyżni; G - Kotlinowy Wierch; acronyms: AF - alkaline fen; CR - reed bed with Carex rostrata; DL - dystrophic lake; L - lake; PF - poor fen; PB - Pinus mugo shrubs on peat bogs; RB - raised bog; SB - Norway spruce bog woodlands; $\mathrm{SP}$ - subalpine Pinus mugo krummholz.

the class Vaccinio-Piceetea are Dicranum scoparium, Hylocomium splendens, Pleurozium schreberi, Ptilium crista-castrensis, Vaccinium myrtillus, V. uliginosum and $V$. vitis-idaea. Other diagnostic species represents typical vegetation of poor fens (Sphagnetalia magellanici), such as Andromeda polifolia, Carex pauciflora, Eriophorum vaginatum, Oxycoccus palustris, Polytrichum strictum, Sphagnum capillifolium, S. magellanicum, S. rubellum.
Typical species for raised bogs (Oxycocco-Sphagnetea) are Aulacomnium palustre, Calypogea azurea and Sphagnum russowi (Table 1). It is worth adding that species representing order Caricetalia nigrae, such as Carex echinata, Carex nigra, Juncus filiformis, Viola palustris, also occur in the patches of $P$. mugo shrubs on peat bogs in the Tatra Mountains, however, their constancy is relatively low (Table 1). 


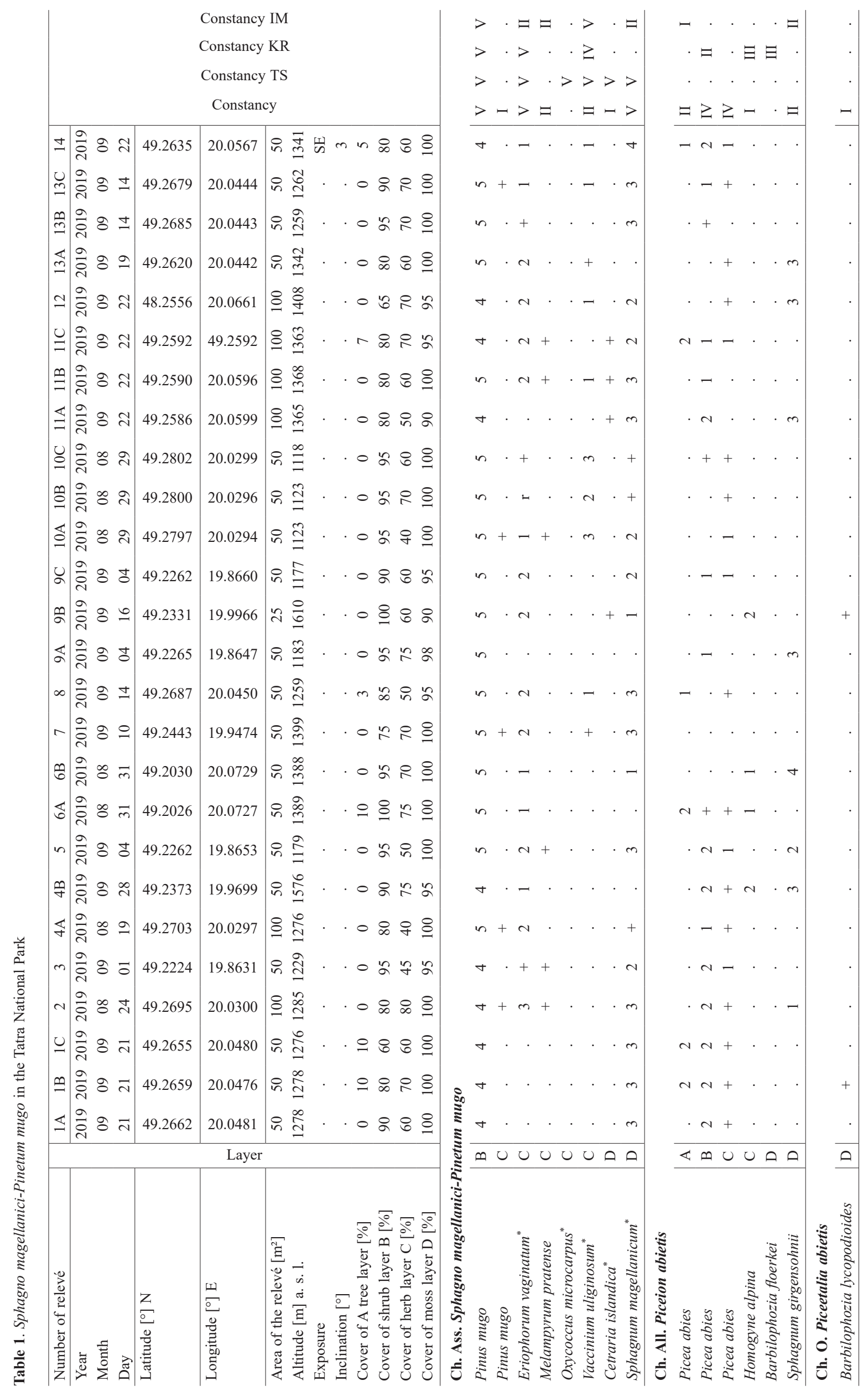




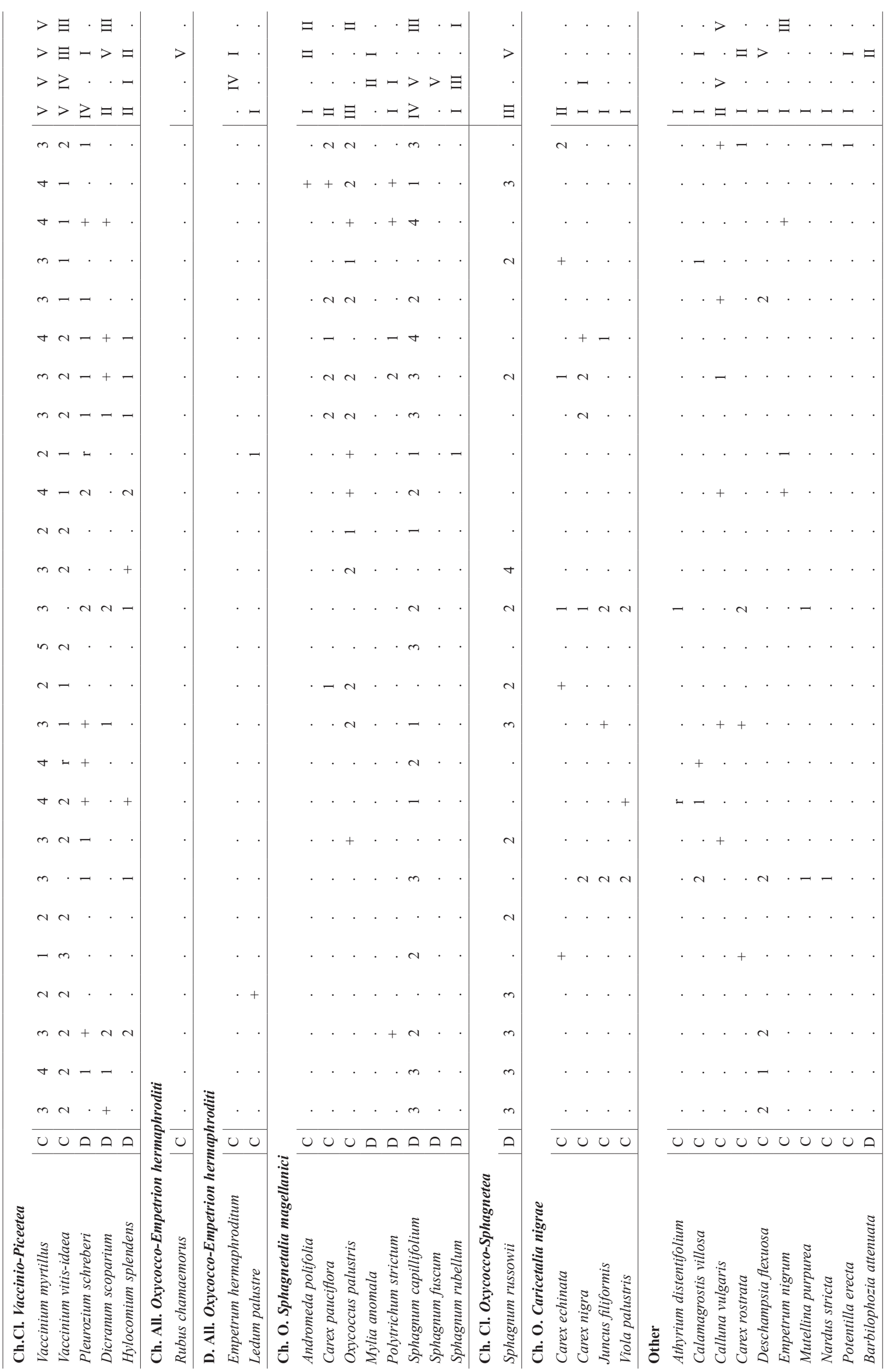




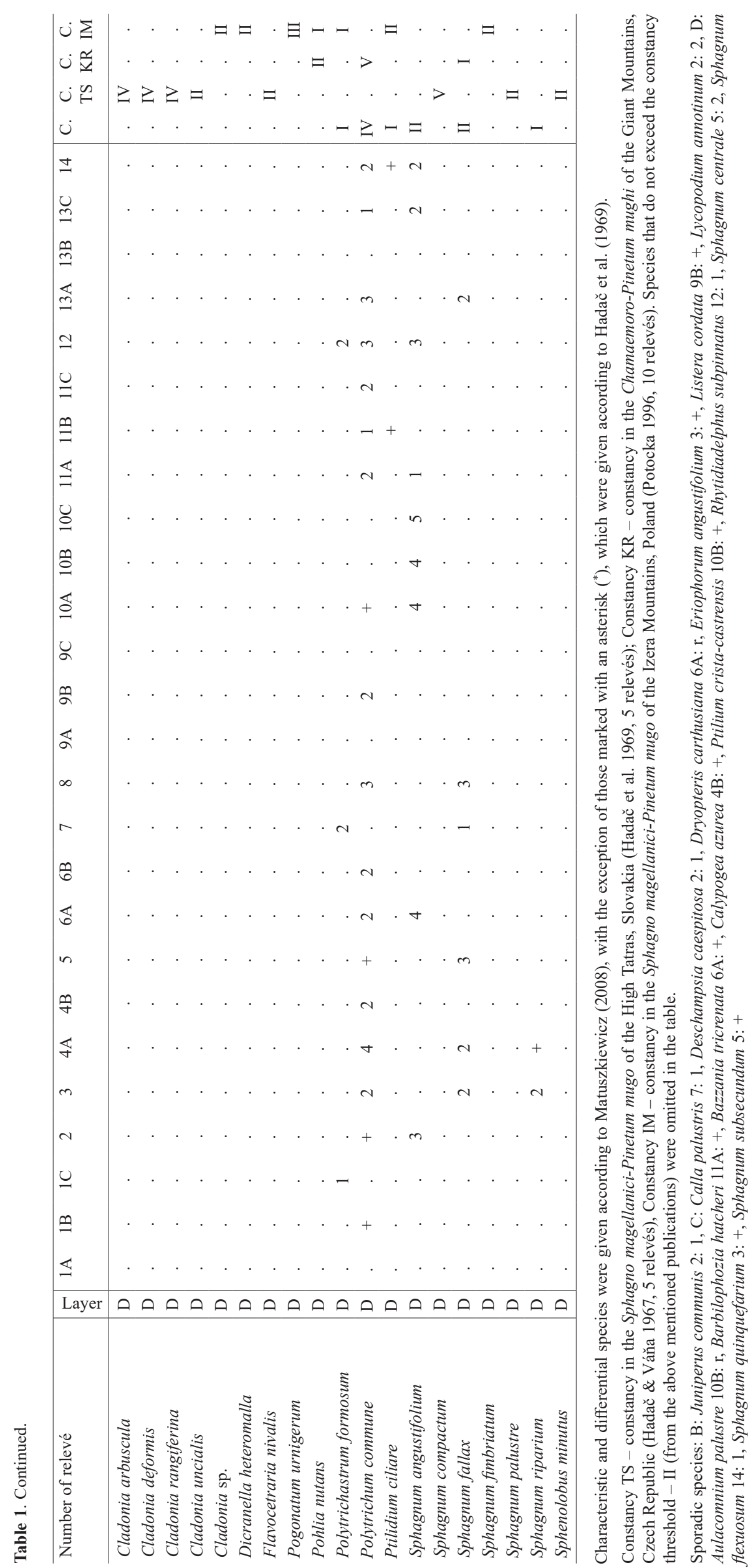



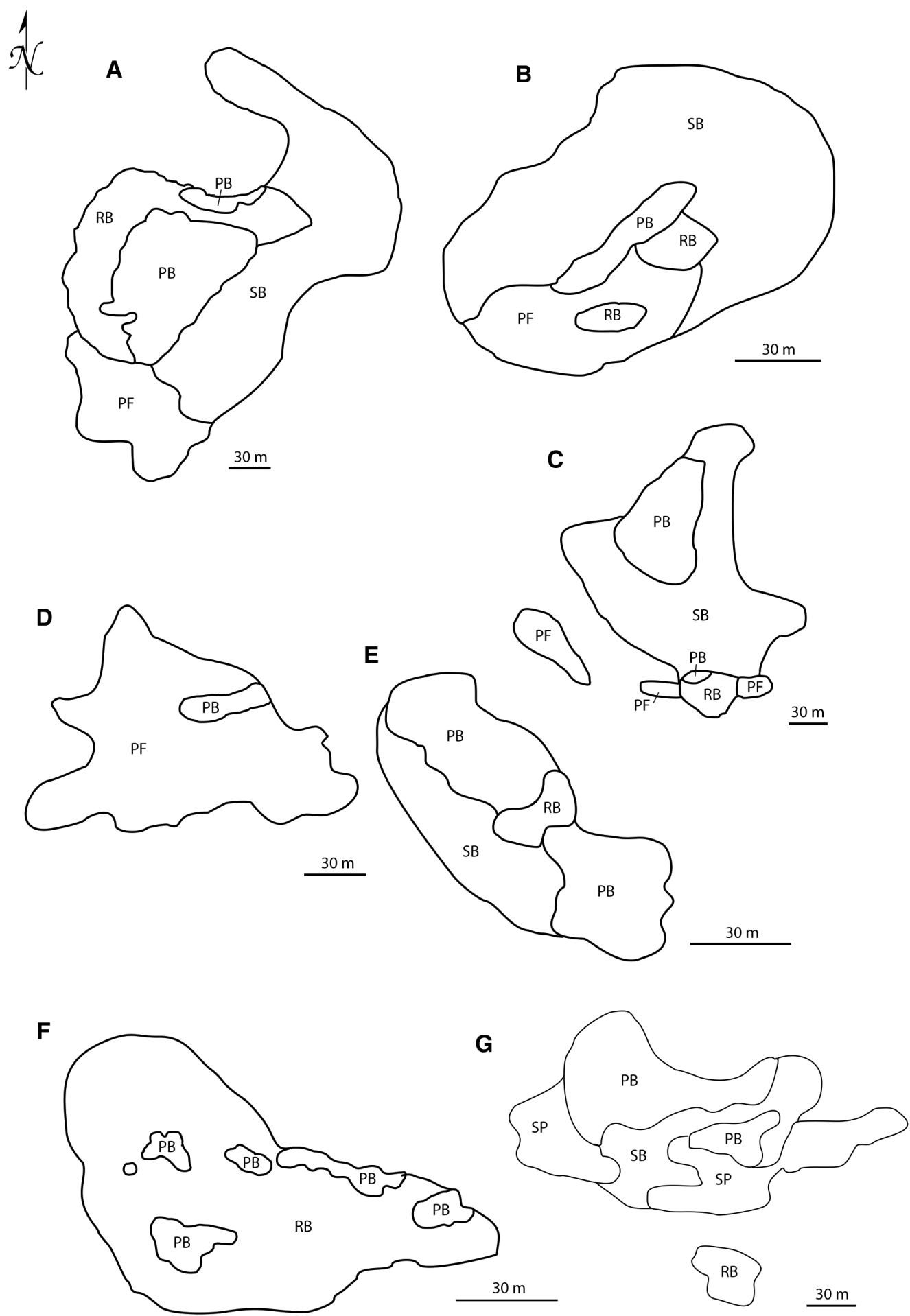

Figure 4. Vegetation types in the study sites. A - Wielka Pańszczycka Młaka; B - Strzelecka Koliba; C - Butorów; D - Wyżnia Pańszczycka Młaka; E - Waksmundzka Polana; F - Waksmundzka Rówień; G - Rybie Stawki; acronyms like in fig. 2.

\section{Peat bogs description}

1. Butorów - rel. 1A-C, Fig. 4C - two patches of P. mugo shrubs - large patch, surrounded by Norway spruce bog woodland, and small patch located at the border of Picea abies woodland and raised bog. The complex includes also poor fens.

2. Goryczkowa Valley - rel. 2, Figs 2E, 3D - a small patch of $P$. mugo shrubs on peat bogs borders poor fens and subalpine dwarf pine krummholz.
3. Kondratowa Valley - rel. 3, Figs 2B, 3C - a small patch of dense $P$. mugo krummholz with small fragments of raised bog in the central part, surrounded by poor fen from South, and subalpine P. mugo shrubs from North.

4. Kotlinowy Wierch - rel. 4A-B, Figs 2C-D, 3Gtwo larger patches of dwarf pine shrubs on peat bogs. Southern patch of dense shrubs covers almost the entire part of that peat bog, leaving just $1 \mathrm{~m}$ wide shrub-less raised bog. Northern patch forms $35 \mathrm{~m}$ long shrubs, whereas on the bordering Eastern peat bog, P. mugo grows 
sparsely. Dwarf pine shrublands adjoin Norway spruce bog woodlands.

5. Litworowy Staw in Gąsienicowa Valley - rel. 5, Fig. 3E - a small patch of $P$. mugo shrubs on peat bog surrounded by poor fen which transits towards the reed bed of Carex rostrata, followed by the lake.

6. Rybie Stawki - rel. 6A-B, Fig. 4G - complex of mires arises along the stream Rybi Potok. Several patches of $P$. mugo shrubs on peat bogs border with poor fens, raised bogs, subalpine dwarf pine krummholz, Norway spruce bog woodlands and reed beds. The thickness of peat reaches $3.75 \mathrm{~m}$ (Obidowicz 1996).

7. Smreczyński Staw - rel. 7, Fig. 3A-a patch of P. mugo shrubs on peat bogs followed by a poor fen with elements of raised bogs occur on Western side of the dystrophic lake. The thickness of peat reaches $3.9 \mathrm{~m}$ (Dyakowska 1932).

8. Strzelecka Koliba - rel. 8, Fig. 4B - P. mugo shrubs on peat bogs form narrow line, separating Norway spruce bog woodlands from poor fen. Furthermore, there is a small patch of raised bog in the middle of that mire.

9. Tomanowa Valley - rel. 9A-C, Figs $2 \mathrm{~F}-\mathrm{G}, 3 \mathrm{~B}-$ complex of mires on a small plateau above the bottom of valley. There are two patches of $P$. mugo shrubs on peat bogs, separated by Norway spruce bog woodlands and fragments of raised bog transitioning towards poor fen.

10. Toporowy Staw Wyżni - rel. 10A-C, Figs 2A, 3F - dense belt of $P$. mugo shrubs on peat bogs encompasses from East and North poor fen with fragments of raised bog, on the Northern side dwarf pine krummholz stretches out for $50 \mathrm{~m}$, bordering raised bog. From West $P$. mugo borders Norway spruce bog woodland. The thickness of peat reaches $4 \mathrm{~m}$. There is a lens of water in the central part of the peat bog, between the layer of peat and lake sediments (Kloss 2020).

11. Waksmundzka Polana - rel. 11A-C, Fig. 4E patches of $P$. mugo shrubs on peat bogs are striated by the fragments of raised bog and surrounded from southeast by Norway spruce bog woodland.

12. Waksmundzka Rówień - rel. 12, Fig. 4F - scattered patches of $P$. mugo shrubs are located in the center of raised bog, surrounded by upper montane Norway spruce forest.

13. Wielka Pańszczycka Młaka - rel. 13A-C, Fig. 4A - in this complex of mires two patches of P. mugo shrublands occur - large patch, surrounded from southeast by Norway spruce bog woodlands and bordering from west with raised bogs, and from south with poor fen. Furthermore, there is a minor belt of $P$. mugo shrubs located north from the raised bog. The thickness of peat reaches $5.4 \mathrm{~m}$ (Obidowicz 1975).

14. Wyżnia Pańszczycka Młaka - rel. 14, Fig. 4D dwarf pine shrubs on peat bogs form narrow belt reaching poor fen which also shows some features of raised bog on the southern side. The thickness of peat reaches here 3.75 m (Obidowicz 1996).

\section{Discussion}

The floristic composition of patches of P. mugo shrubs described in this study is similar to those observed by
Obidowicz (1975). The only species which were not found in 2019 were Barbilophozia florkei, Calypogea sphagnicola, Dicranum undulatum, Gymnocolea inflata and Lophozia wenzelii. However, Gymnocolea inflata occurred frequently in the neighboring peat bogs. Furthermore, Obidowicz (1975) mentioned Melampyrum sylvaticum in these shrublands, which is a mistake. This species does not grow on peat bogs, unlike similar Melampyrum pratense. According to Matuszkiewicz (2008) it is a characteristic species for the Pino mugo-Sphagnetum.

Hadač et al. (1969) described from the Slovakian side of the Tatras plant community of $P$. mugo shrubs on peat bogs, called Sphagno magellanici-Pinetum mugo Hadač, Ježek et Březina 1969. It was detected from the Trojrohé pleso in the High Tatras (1600 m a.s.1.). Characteristic species of that shrublands include Cetraria islandica, Eriophorum vaginatum, Oxycococus microcarpus, Pinus mugo, Sphagnum magellanicum and Vaccinium uliginosum (Hadač et al. 1969). It is worth emphasizing that, except for Oxycoccus microcarpus, all of the above mentioned species also occur in similar shrublands in the Polish Tatras. Oxycoccus microcarpus is a rare and endangered species in the Polish Tatra National Park. Its distribution is limited to only four localities (Ociepa et al. 2020). All of them are situated in mires neighboring $P$. mugo shrubs on peat bogs (Polana Waksmundzka, Wyżnia Pańszczycka Młaka, Toporowy Staw Wyżni, Dolina Tomanowa). Therefore, it is possible that $O x y$ coccus microcarpus also grows in Polish Tatras on such shrublands, but has not been found there yet. The other difference between $P$. mugo shrubs growing on both sides of the national border is a lack of Picea abies in the Slovakian Tatras. This could be explained by the higher elevation of analyzed dwarf pine krummholz, located above the timberline. Furthermore, in the Slovakian Tatras grows Empetrum hermaphroditum, whereas on the Polish side Empetrum nigrum grows. This can also be explained by the altitude difference. Empetrum nigrum grows in the lower montane belt and occasionally in the upper montane zone, whereas E. hermaphroditum occurs in the subalpine and alpine zone (Combik \& Mirek 2015). In addition, Sphagnum compactum frequently occurs on the Slovakian side. This species has not been detected so far in P. mugo shrubs on peat bogs in the Polish Tatras. It dominates the moss layers in the Trichophoro cespitosi-Sphagnetum compacti and Carici lachenalii-Eriophoretum vaginati associations, which occur in the High Tatras (1500-2100 m a.s.1.) (Sekulová et al. 2011).

P. mugo shrubs were usually classified in the association Pino mugo-Sphagnetum Kästn. et Flössn. 1933 em. Neuh. 1969 corr Dierss. 1975 (Herbich et al. 2004, Matuszkiewicz 2008, Matuszkiewicz et al. 2013). According to Šibík et al. (2008), this classification is incorrect. Kästner i Flössner (1933) described an association called Pinetum uncinatae. Nauhäusl (1969) changed its name to Pino-Sphagnetum. However, this was erroneous, because the updated name cannot substitute welldefined syntaxon. Furthermore, these two associations are formed by two different species of pines (Pinus) (Šibík et al. 2008). The correct name of the P. mugo shrubs on 
peat bogs is Chamaemoro-Pinetum mughi (Zlatník 1928) Hadač et Váňa 1967. However, Šibík et al. (2008) proposed that Sphagno magellanici-Pinetum mugo Hadač, Ježek et Březina 1969 should be treated as a correct name - nomina conservanda, due to the fact, that eponymous species Rubus chamaemorus does not occur within the entire range of distribution of $P$. mugo shrubs on peat bogs.

P. mugo shrubs on peat bogs in Sudetes have similar species composition as in the Tatras (Żołnierz et al. 2012). However, Rubus chamaemorus does not occur in the Tatra Mountains. Presence of this species was the reason to treat $P$. mugo shrubs on peat bogs as a separate association, Chamaemoro-Pinetum mughi (Zlatník 1928) Hadač et Váňa 1967 (Kwiatkowski 2007). Such concept is not accepted by Šibík et al. (2008), who treat P. mugo shrubs on peat bogs in the Sudetes and Carpathians as one plant association, Sphagno magellanici-Pinetum mugo, common to both mountain ranges.

Another important and disputed issue is an affiliation of $P$. mugo shrubs to the certain syntaxonomic class. Diagnostic species of this association belong either to the class of peat bogs vegetation Oxycocco-Sphagnetea Br.-Bl. et Tx. 1943, or coniferous forests Vaccinio-Piceeteta Br.-B1. 1939. According to some authors, Sphagno magellanici-Pinetum mugo should be classified to the Oxycocco-Sphagnetea class (Hadač \& Váňa 1967, Hadač et al. 1969, Potocka 1996, Soltes et al. 2001, Matuszkiewicz 2008, Herbich et al. 2004, Matuszkiewicz 2013), whereas others (for example Seibert 1992) claim that such vegetation belongs to Vaccinio-Piceetea. Sibík et al. (2008) suggest another solution and includes that association to Vaccinio uliginosi-Pinetea sylvestris Passarge 1968. This class encompasses azonal, oligotrophic coniferous tree- and shrub- communities, more or less peaty, in the boreal and mountain region (Šibík et al. 2008)

Concluding, P. mugo shrubs on peat bogs in the Polish Tatra National Park occur on a relatively small area. They should be classified according to Šibík et al. (2008) as Sphagno magellanici-Pinetum mugo. These shrublands are similar to those growing on the Slovakian side of the Tatras.

\section{Acknowledgements}

This study was partly financed by the State Forest Fund of the Polish State Forests granted to the Tatra National Park in 2019 and 2020. Authors would like to thank Prof. Adam Stebel from the Medical University of Silesia for his help in identification of mosses and liverworts and Dr Michał Węgrzyn from the Jagiellonian University for his help in identification of lichens.

We dedicate this paper to Dr Anna Koczur, who was collecting data in the field, but died during preparation of the manuscript.

\section{References}

Balcerkiewicz, S. 1984. Roślinność wysokogórska Doliny Pięciu Stawów Polskich w Tatrach i jej przemiany antropogeniczne. Wydawnictwo Naukowe Uniwersytetu A. Mickiewicza, Seria Biologia 25: 1-191.

Braun-Blanquet, J. 1964. Pflanzensoziologie - Grundzüge der Vegetationskunde, pp. 865. Springer Verlag, Wien, New York.
Combik, M. \& Mirek, Z. 2015. Estimating of the effectiveness of species identification by sequencing of two chloroplast DNA loci (matK and rbcL) in selected groups of Polish flora. DNA Barcodes 15: 17-26.

Derkacz, M. 2006. Jeziora i torfowiska w Dolinie Suchej Wody w Tatrach i ich geneza wytopiskowa. Przeglad Geologiczny 54(1): 73-75.

Dyakowska, J. 1932. Analiza pyłkowa kilku torfowisk. Acta Societatis Botanicorum Poloniae 9(3-4): 473-530.

Dzwonko, Z. 2007. Przewodnik do badań fitosocjologicznych, pp. 304. Instytut Botaniki UJ, Sorus, Poznań - Kraków.

Faliński, J. B. 1990. Kartografia geobotaniczna. 2. Kartografia fitosocjologiczna, pp. 284. PPPWK, Warszawa - Wrocław.

Fałtynowicz, W. \& Kossowska, M. 2016. The lichens of Poland. A fourth checklist. Acta Botanica Silesiaca Monographiae 8: 1-122.

Hadač, E. \& Váňa, J. 1967. Plant communities of mires in the western part of the Krkonoše Mountains, Czechoslovakia. Folia Geobotanica \& Phytotaxonomica 2(3): 213-254. https://doi.org/10.1007/ bf02854617

Hadač, E., Ježek, V. \& Březina, P. 1969. Rostlinná společenstva Trojrohého plesa ve Vysokých Tatrách. Zbornik Prac o Tatranskom Národnom Parku 11: 481-494.

Herbich, M., Potocka, J. \& Kwiatkowski, W. 2004. Bory i lasy bagienne. A. Opis siedliska głównego typu. In: Herbich, J. (ed.), Lasy i Bory. Poradniki ochrony siedlisk i gatunków Natura 2000 - podręcznik metodyczny T. 5, pp. 171-174. Ministerstwo Środowiska, Warszawa.

Kauzal, P. \& Zięba, A. 2018. Ramsar w Tatrach. Tatry 64: 11.

Kästner, M. \& Flößner, W. 1933. Die Pflanzengesellschaften des westfälischen Berg - und Hüggellandes. II Teil. Landesverein Sächsischer Heimatschutz 2: 1-208.

Kloss, M. 2020. Postglacjalna sukcesja roślinności na mszarnym torfowisku ,,Toporowy Staw Wyżni” w Tatrach. VI Konferencja Przyroda Tatrzańskiego Parku Narodowego a Człowiek. Zmiany w Tatrach - zagrożenia istniejące i potencjalne. Zakopane. Zeszyt abstraktów pp. 60-63.

Kwiatkowski, P. 2007. Stan poznania i przegląd systematyczny zbiorowisk roślinnych polskich Karkonoszy. Przyroda Sudetów Zachodnich 10: 29-50.

Łajczak, A. 2014. Rola podłoża w rozwoju torfowisk w polskich Karpatach. Studia Limnologica et Telmatologica 8(1): 19-36.

Matuszkiewicz, W. 2008. Przewodnik do oznaczania zbiorowisk roślinnych Polski. In: Faliński, J. B. (ed.), Vademecum Geobotanicum Wydawnictwo Naukowe PWN, Warszawa. 3: 1-537.

Matuszkiewicz, W., Sikorski, P., Szwed, W. \& Wierzba, M. 2013. Zbiorowiska roślinne Polski. Lasy i zarośla, pp. 518. Wydawnictwo Naukowe PWN, Warszawa.

Mirek, Z., Piękoś-Mirkowa, H., Zając, A. \& Zając, M. 2002. Flowering plants and pteridophytes of Poland. A checklist. Biodiversity of Poland. Vol. 1. W. Szafer Institute of Botany, Polish Academy of Sciences, Kraków.

Mirek, Z., Binkiewicz, B., Czerny, M. \& Bielecki, M. 2013a. Operat ochrony ekosystemów nieleśnych. Msckr. pp. 157. KRAMEKO sp. z o. o., Kraków.

Mirek, Z., Jaworski, A., Holeksa, J., Czerny, M., Krawiec, A., Mroczek, K., Szmalec, T., Łaptosz, J., Myjak, P., Mitka, K., Bodzioch, R. \& Lomber, J. 2013b. Operat ochrony ekosystemów leśnych. Msckr. pp. 175. KRAMEKO sp. z o. o., Kraków.

Neuhäusl, R. 1969. Systematisch-Soziologische Stellung Der Baumreichen Hochmoorgesellschaften Europas. Vegetatio 18(1): 104-21.

Obidowicz, A. 1975. Entstehung und Alter einiger Moore im nördlichen Teil der Hohen Tatra. Fragmenta Floristica et Geobotanica 21(3): 281-323.

Obidowicz, A. 1996. A Late Glacial-Holocene history of the formation of vegetation belt in the Tatra Mts. Acta Paleobotanica 36(2): 159-206.

Ochyra, R., Żarnowiec, J. \& Bednarek-Ochyra, H. 2003. Census catalogue of Polish mosses. Biodiversity of Poland. Vol. 3. W. Szafer Institute of Botany, Polish Academy of Sciences, Kraków. 
Ociepa, A. M., Koczur, A. \& Zięba, A. 2020. New localities of rare peat bog species in Tatra National Park and its adjacent area. Fragmenta Floristica et Geobotanica Polonica 27(2): 395-408. https://doi. org/10.35535/ffgp-2020-0023

Pawłowski, B., Sokołowski, M. \& Wallisch, K. 1928. Zespoły roślinne w Tatrach. Cz. VII. Zespoły roślinne i flora doliny Morskiego Oka. Bulletin International De l'Académie Polonaise Des Sciences et Des Lettres Classe Des Sciences Mathématiques et Naturelles, Série B: Sciences Naturelles 1927, Suppl. 2: 205-272.

Potocka, J. 1997. Flora i zbiorowiska wybranych torfowisk Gór Izerskich. II. Charakterystyka fitosocjologiczna. Acta Universitatis Wratislaviensis. 1936 Prace Botaniczne 73: 115-144.

Potocka, J. 2001. Torfowiska polskiej strony Gór Izerskich - charakterystyka obiektów. Przyroda Sudetów Zachodnich 4: 43-57.

Ramsar sites information service. https://rsis.ramsar.org/ris/2341

Rozporządzenie Ministra Klimatu i Środowiska z dnia 6 lipca 2021 r. w sprawie ustanowienia planu ochrony dla Tatrzańskiego Parku Narodowego Dz. U. 2021, poz. 1462.

Seibert, P. 1992. Klasse Vaccinio-Piceetea Br.-Bl. in Br.-Bl. et al. 39. In: Oberdorfer, E. (ed.), Süddeutsche Pflanzengesellschaften. Teil. 4, pp. 53-80. G. Fischer, Jena.

Sekulová, L., Hájek, M., Hájková, P., Mikulášková, E. \& Rozbrojová, Z. 2011. Alpine wetlands in the West Carpathians: vegetation survey and vegetation-environment relationships. Preslia 83: 1-24.

Šibík, J., Ditě, D., Šibíkova, I. \& Pukajová, D. 2008. Plant communities dominated by Pinus mugo agg. in Central Europe - comparison of the oligotrophic communities rich in Sphagnum. Phytocoenologia 38(3): 221-238. https://doi.org/10.1127/0340-269x/2008/0038-0221

Šibík, J., Šibíkova, I. \& Kliment, J. 2010. The subalpine Pinus mugo-communities of the Carpathians with a European perspective.
Phytocoenologia 40(2-3): 155-188. https://doi.org/10.1127/0340$269 \mathrm{x} / 2010 / 0040-0436$

Skiba, S., Koreň, M., Drewnik, M. \& Kukla, J. 2015. Gleby (Soils) In: Dąbrowska, K. \& Guzik, M. (eds), Atlas of the Tatra Mountains Abiotic Nature: VI.1. Tatrzański Park Narodowy, Zakopane.

Šoltés, R., Hájek, M. \& Valachovič, M. 2001. Oxycocco-Sphagnetea. In: Valachovič, M. (ed.), Raslinné společenstvá Slovenska. 3. Vegetácia mokradí. pp. 275-296. Veda, Bratislava.

Szafer, W., Pawłowski, B. \& Kulczyński, S. 1927. Die Pflanzenassoziationen des TatraGebirges. III Teil: Die Pflanzenassoziationen des Kościeliska Tales. Bulletin International De l'Académie Polonaise Des Sciences et Des Lettres Classe Des Sciences Mathématiques et Naturelles. Série B: Sciences Naturelles, Suppl. II: 13-78.

Szczegółowa mapa geologiczna Tatr w skali 1:10 000 (SMGT) 2016. Państwowy Instytut Geologiczny - Państwowy Instytut Badawczy, Warszawa.

Szweykowski, J. 2006. An annotated checklist of Polish liverworts and hornworts. Biodiversity of Poland. Vol. 4. W. Szafer Institute of Botany, Polish Academy of Sciences, Kraków.

Tichý, L. 2002. JUICE, software for vegetation classification. Journal of Vegetation Science 13: 451-453.

Zasadni, J. 2015. Rzeźba wybranych regionów Tatr Wysokich. Mapa 2 Dolina Suchej Wody (Relief of selected parts of the High Tatra Mountains. Map 2 Sucha Woda Valley). In: Dąbrowska, K. \& Guzik, M. (eds), Atlas of the Tatra Mountains - Abiotic Nature: VI.6. Tatrzański Park Narodowy, Zakopane.

Żołnierz, L., Wojtuń, B. \& Przewoźnik, L. 2012. Ekosystemy nieleśne Karkonoskiego Parku Narodowego, pp. 51. Karkonoski Park Narodowy, Jelenia Góra. 